\title{
Поведение соединений азота и их трансформация в системе почва- подземные воды сельскохозяйственных ландшафтов Западной Сибири
}

\author{
Е.А. Солдатова ${ }^{1 凶}$, Д. В. Пургина² \\ ${ }^{1}$ Институт геохимии и аналитической химии имени В. И. Вернадского Российской академии наук, \\ Российская Федераиия \\ (119991, г. Москва, ул. Косыгина, 19) \\ ${ }^{2}$ Нацииональный исследовательский Томский политехнический университет, Российская Федерация \\ (634050, г. Томск, пр. Ленина, 30)
}

\begin{abstract}
Аннотация: Цель - рассмотреть особенности миграции и трансформации соединений азота в системе почва-подземные воды на примере сельскохозяйственных ландшафтов Томского района Томской области. Материалы и методы. Исследования проводились на основе результатов химического и микробиологического анализа образцов подземных вод и почв, а также анализа изотопного состава нитрат-иона, растворенного в подземных водах. Химический состав подземных вод и почв определялся методами титриметрии, потенциометрии, пламенной фотометрии, фотоколориметрии, флуориметрии и высокотемпературного-каталитического окисления. Микробиологический анализ образцов подземных вод и почв осуществлялся путем культивирования групп микроорганизмов, принимающих участие в круговороте азота, на питательных средах. Изотопный состав нитрат-иона проанализирован методом бактериальной денитрификации с использованием изотопного масс-спектрометра, соединенного с дополнительным модулем для пробоподготовки следовых газов. Результаты. Обработка полученной геохимической информации с применением аппарата математической статистики позволила выявить процессы, происходящие с соединениями азота в течение сельскохозяйственного сезона и определить их локализацию в системе почва-подземные воды, включая влияние микрофлоры на трансформацию соединений азота. Проведенные исследования также позволили выявить некоторые взаимосвязи между формующейся геохимической обстановкой в водоносном горизонте и процессами, происходящими в почве.
\end{abstract}

Ключевые слова: биогеохимический цикл азота, водная миграция, нитраты, аммоний, изотопный состав нитратов, микробиологические процессы, Томская область.

Благодарности: Авторы благодарят К. В. Зиновик, В. В. Крамаренко и Т. С. Спиридонова за помощь в организации и проведении геохимического опробования и пробоподготовки образцов почв.

Источник финансирования: исследования выполнены при финансовой поддержке РНФ, проект 17-77-10017.

Для цитирования: Солдатова Е. А., Пургина Д. В. Поведение соединений азота и их трансформация в системе почва-подземные воды сельскохозяйственных ландшафтов Западной Сибири // Вестник Воронежского государственного университета. Серия География. Геоэкология, 2020, № 4, с. 32-43. DOI: https://doi.org/10.17308/geo.2020.4/3063

\section{ВВЕДЕНИЕ}

Изучение биогеохимического цикла азота является важной составляющей исследования круговорота химических элементов и их миграции, поскольку содержание и баланс форм азота - это

() Солдатова Е.А., Пургина Д.В., 2020

\ Солдатова Евгения Александровна, e-mail: sea@geokhi.ru

Контент доступен под лицензией Creative Commons Attribution 4.0 License. один из показателей экологического благополучия экосистем. Азот, как биогенный элемент, используется для интенсификации физиологических процессов у растений путем внесения в систему соответствующих удобрений. Нерациональное применение удобрений приводит к потерям азота и заг- 


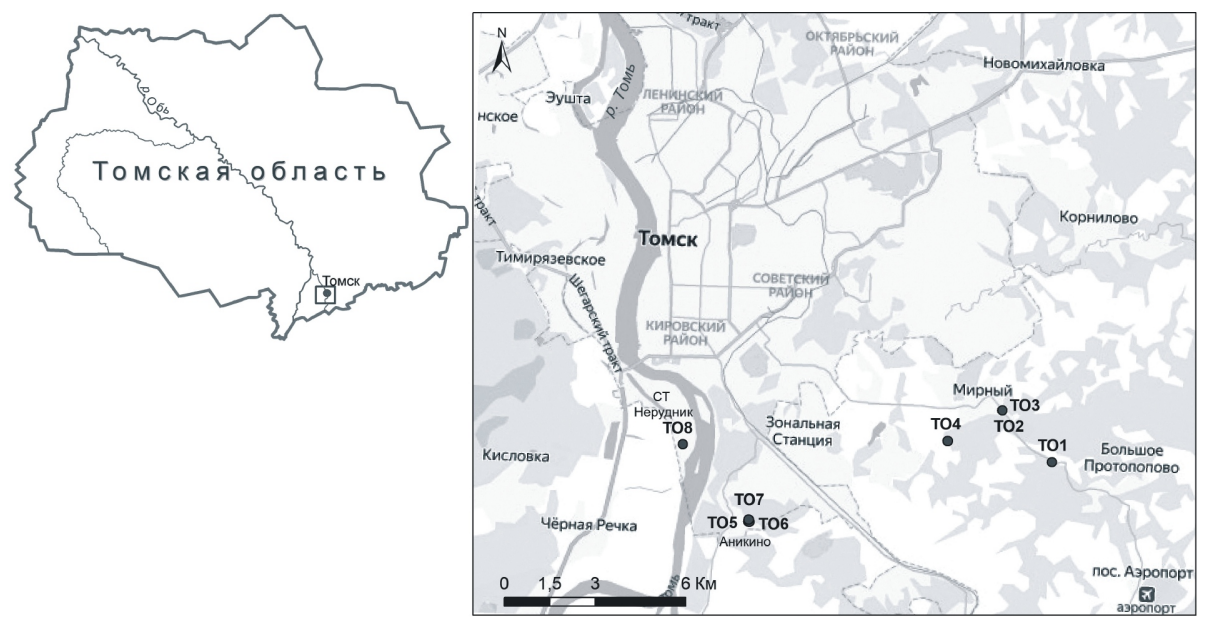

Puc. 1. Расположение точек опробования подземных вод и почв на территории Томского района (Томская обл., Россия)

[Fig. 1. Location of the sampling points of groundwater and soils within Tomsk district (Tomsk region, Russia)]

рязнению подземных вод $[4,14]$. Состояние вод непосредственно влияет на здоровье населения, поскольку зачастую в сельскохозяйственных районах отсутствуют централизованные системы водоснабжения. Выбор нами системы почва-подземные воды обусловлен тем, что формирование состава подземных вод, в частности обогащение их соединениями азота, начинается в почвенном горизонте [16]. Таким образом, комплексное изучение системы почва-подземные воды в пределах сельскохозяйственных ландшафтов необходимо для мониторинга экологического состояния природно-антропогенных экосистем в целом и подземных вод в частности.

Изучение миграции соединений азота в пределах сельскохозяйственных ландшафтов Томского района Томской области проведено в рамках комплексных исследований биогеохимического цикла азота агроландшафтов различных типов и климатических зон. Район исследований расположен на юге Западной Сибири и характеризуется умеренно-континентальным климатом со среднегодовой температурой от $-0,5$ до $1,5{ }^{\circ} \mathrm{C}$ и среднегодовым количеством осадков 500-600 мм/год [2, 8].Сельскохозяйственные ландшафты здесь имеют ограниченное распространение на фоне лесных и лесостепных ландшафтов с преобладанием дерново-подзолистых, подзолистых и серых лесных почв [6]. Необходимо отметить, что дополнительная антропогенная нагрузка на экосистему в пределах агроландшафтов района исследований обусловлена отсутствием централизованных систем водоотведения и канализации.

\section{МАТЕРИАЛЫ И МЕТОДЫ}

\section{Полевые исследования}

Полевые исследования были проведены на территории Томского района в 2017-2018 годов. В ходе исследований были опробованы: колодец на границе Протопоповского припоселкового кедровника, не затронутого сельскохозяйственной детальностью (ТО1), район поселков Мирный и Трубачево (ТО2-ТО4), где развито сельскохозяйственное производство в промышленных масштабах (выращивание сельскохозяйственных культур, в том числе в теплицах, крупного рогатого скота и других копытных, а также переработка сельхоз продукции), район поселка Аникино (ТО5-ТО7) и садовое товарищество (СТ) Нерудник (ТО8), где широко распространены частные садово-огороднические кооперативы (рис. 1). В каждой точке опробования были отобраны пробы подземных вод и почв. Подземные воды отобраны из частных колодцев и скважин, используемых населением в питьевых и хозяйственно-бытовых целях, с глубины от 1 до 20 м. Пробы почвы отобраны в интервалах 0,1-0,3 м, где микроорганизмы наиболее активны, и 0,9-1,1 м для анализа динамики химического и микробиологического состава почв.

Для определения концентрации $\mathrm{HCO}_{3}^{-}, \mathrm{SO}_{4}{ }^{2-}$, $\mathrm{Cl}^{-}, \mathrm{Ca}^{2+}, \mathrm{Mg}^{2+}, \mathrm{Na}^{+}, \mathrm{K}^{+}, \mathrm{NO}_{3}^{-}, \mathrm{NO}_{2}^{-}, \mathrm{NH}_{4}^{+}, \mathrm{CO}_{2}, \mathrm{C}_{\text {opr }}$, $\mathrm{N}_{\text {обш }}$, а также химического потребления кислорода (ХПК) и перманганатной окисляемости (ПОК), воду отбирали в пластиковые бутылки объемом 1,0-1,5 л предварительно трижды промытые исследуемой водой. Показатели $\mathrm{Eh}, \mathrm{pH}$ и содержание растворенного кислорода измерялись in situ пор- 
тативными анализаторами COM100, ORP200, PH200 (HM Digital, Южная Корея), и оксиметром AZ8401 Hanheld DO Meter (AZ Instrument, Китай). Для определения содержания стабильных изотопов $\delta^{15} \mathrm{~N}_{-} \mathrm{NO}_{3}^{-}$и $\delta^{18} \mathrm{O}-\mathrm{NO}_{3}^{-}$на точке отбора для снижения вероятности протекания реакций, связанных с жизнедеятельностью микроорганизмов, пробу воды фильтровали через стерильный мембранный фильтр из полиэфирсульфона с размером пор 0,22 мкм с помощью шприца, предварительно промытого исследуемой водой в пластиковые бутылки объемом 0,3 л, также предварительно трижды промытые исследуемой водой. Первые 5 мл пробы при фильтрации исключались. Пробы для микробиологического анализа отбирали в стеклянные бутылки объемом 250 мл с использованием стерильных перчаток. Стерильную емкость для отбора проб открывали под струей воды или в емкости, заполненной исследуемой водой, удаляя пробку вместе со стерильным колпачком. После наполнения емкость немедленно закрывали стерильной пробкой, обеспечивающей герметичность, и стерильным колпачком. При заполнении емкости оставляли пространство между пробкой и поверхностью воды, чтобы пробка не смачивалась при транспортировании и для обеспечения перемешивания пробы перед анализом.

С момента отбора и до момента доставки в лабораторию пробы хранились охлажденными в недоступном для света месте, температура поддерживалась с помощью хладоэлементов. Отбор образцов почв для химического и микробиологического анализа производился в стерильные пластиковые пакеты.

\section{Химический анализ}

Химический анализ проб воды выполнен в Проблемной научно-исследовательской лаборатории гидрогеохимии Инжинирингового центра ТПУ (г. Томск). Концентрация $\mathrm{HCO}_{3}{ }^{-}$определялась методом потенциометрического титрования 0,1 н раствором $\mathrm{HCl}$ (Анион-7051, Инфраспак-Аналит, Россия); содержания $\mathrm{SO}_{4}{ }^{2-}, \mathrm{Cl}^{-}$определялись методом ионной хроматографии (ICS 2000, Dionex, США); концентрация $\mathrm{Ca}^{2+}$ определена с помощью титрование трилоном Б (концентрация $\mathrm{Mg}^{2+}$ рассчитана из значения общей жесткости и концентрации $\mathrm{Ca}^{2+}$ ); содержания $\mathrm{Na}^{+}, \mathrm{K}^{+}$определены методом пламенной фотометрии (ПФА-378, Юнико-Сис, Россия); содержание $\mathrm{CO}_{2}$ определено титрованием 0,1 н раствором $\mathrm{NaOH}$; концентрации $\mathrm{NO}_{3}^{-}, \mathrm{NO}_{2}^{-}, \mathrm{NH}_{4}^{+}$определены с помощью фотоколориметрии (КФК-2, 3ОМЗ, Россия). Значение
ПОК определялось титрованием раствором перманганата калия, значение ХПК проанализировано с помощью флуориметрии (Флюорат 02-3М, Люмэкс, Россия). Содержания $\mathrm{C}_{\text {орг }}$ и $\mathrm{N}_{\text {общ }}$ определено с помощью высокотемпературного каталитического окисления (Vario TOC cube, Elementar, Германия).

Химический анализ образцов почв выполнен в Федеральном государственном бюджетном учреждении «Станция агрохимической службы «Томская» и Проблемной научно-исследовательской лаборатории гидрогеохимии Инжинирингового центра ТПУ (г. Томск). Процедура пробоподготовки включала высушивание грунта до воздушно-сухого состояния, исключение из пробы остатков корней растений, растирание в агатовой ступке, просеивание через сито с диаметром отверстий 1 мм. После растирания и просеивания пробы распределяли слоем не более 1 см и отбирали пробу из 5 точек для анализа. Водную вытяжку готовили объемно-весовым способом (1:5). Значения рН и концентрации $\mathrm{NO}_{3}{ }^{-}, \mathrm{NH}_{4}{ }^{+}$определены методом потенциометрии (Анион-7051, Инфраспак-Аналит, Россия); содержание Сорг проанализировано титрованием 0,2 н раствором соли Мора (по методу Тюрина); содержание $\mathrm{N}_{\text {общ }}$ определено методом высокотемпературного каталитического окисления (Vario TOC cube, Elementar, Германия).

Анализ изотопного состава нитратов, растворенных в воде

Изотопный анализ нитратов, растворенных в грунтовых водах, выполнен в лаборатории ISOFYS Гентского университета (г. Гент, Бельгия). Определение изотопного состава нитрат-иона ( $\delta{ }^{15} \mathrm{~N}-\mathrm{NO}_{3}{ }^{-}$и $\left.\delta^{18} \mathrm{O}-\mathrm{NO}_{3}^{-}\right)$в пробах подземных вод произведено методом бактериальной денитрификации [17, 21, 22] с использованием изотопного масс-спектрометpa SerCon 20-20 IRMS (Sercon Ltd., Великобритания), соединенного с дополнительным модулем для пробоподготовки следовых газов ANCA TGII (Automated nitrogen carbon analyser - Trace gases, PDZ Europa Ltd., Великобритания). Содержания изотопов были выражены через $\delta$ в \%о относительно мировых стандартов и определяются по уравнению:

$$
\delta=\left(\left(R_{\text {обр }}-R_{c m}\right) / R_{c m}\right) * 1000,
$$

где $R_{\text {обр }}$ и $R_{c m}$ - изотопные отношения ${ }^{18} \mathrm{O} /{ }^{16} \mathrm{O}$ или ${ }^{15} \mathrm{~N} /{ }^{14} \mathrm{~N}$ для образца и стандарта соответственно. Значения $\delta^{18} \mathrm{O}$ приведены относительно стандарта VSMOW (международный стандарт изотопного состава среднеокеанической воды), в качестве 
стандарта $\delta{ }^{15} \mathrm{~N}$ принят $\mathrm{N}_{2}$ в атмосферном воздухе $\left(\delta{ }^{15} \mathrm{~N}\right.$ AIR).

\section{Анализ микрофлоры подземных вод и почв}

Микробиологический состав образцов почв и подземных вод определен в Сибирском научноисследовательском институте Сельского хозяйства и торфа и в Проблемной научно-исследовательской лаборатории гидрогеохимии Инжинирингового центра ТПУ (г. Томск).

Для изучения микрофлоры почвы проводили диспергирование и десорбцию клеток с поверхности почвенных частиц следующим образом. Навеску почвы 1 г доводили путем добавления стерильной воды до пастообразного состояния, растирая в ступке в течение 5 минут. Затем помещали в колбу с объемом 99 мл. Взбалтывали в течение 30 минут и после готовили серию последующих предельных разведений на стерильной воде.

Для определения азотфиксирующих микроорганизмов в пробах подземных вод и почв использованы среда Эшби, среда Федорова в модификации Калининской, среда Виноградского для выделения свободноживущих анаэробных азотфиксирующих бактерий рода Clostridium. Для культивирования аммонификаторов использовали мясопептонный бульон (МПБ). Для количественного определения аммонификаторов были сделаны посевы методом предельных разведений. Актуальная активность азотобактера определяется методом Виноградского. Для обнаружения нитрифицирующих бактерий использовали среду Сориана и Уокера и среду Ватсона и Вотербари, для их обнаружения проводили качественные реакции на нитриты с реактивом Грисса и на нитраты с дифениламином. Для получения накопительной культуры денитрифицирующих микроорганизмов использовали среду Гильтая, для количественного определения денитрификаторов были сделаны посевы методом предельных разведений, а также произведены посевы на твердую питательную среду Омелянского и мясопептонный агар [7]. Так же дополнительно производился посев на простую среду для денитрификаторов, так как численность микроорганизмов этой группы в почвах, отобранных в 2018 году была очень низкой. Состав простой среды, г/л: $\mathrm{K}_{2} \mathrm{HPO}_{4}-0,5 ; \mathrm{MgSO}_{4} * 7 \mathrm{H}_{2} \mathrm{O}-0,2$; $\mathrm{KNO}_{3}-2,0$; сегнетова соль $-20,0$.

\section{Камеральная обработка данных}

Камеральная обработка данных производилась с применением методов математической статистики в программах MS Excel и Statistica 10. При выборе метода статистической обработки данных учитывался закон распределения выборок, представляющих собой концентрации компонента. Гипотеза о соответствии распределения нормальному или логнормальному закону принималась на основе критериев, предложенных в [1]. В качестве оценки математического ожидания для компонентов, поведение которых описывается нормальным законом распределения, принималось среднее арифметическое; для компонентов, поведение которого подчиняется логнормальному закону - среднее геометрическое. Если распределение не подчиняется выше упомянутым законам распределения, в качестве оценки математического ожидания принималась медиана.

В результате было обнаружено, что поведение некоторых компонентов не подчиняется нормальному закону распределения, поэтому функциональные зависимости между поведением компонентов определялись в основном с помощью рангового коэффициента корреляции Спирмена при заданном уровне значимости $p<0,05$. Для данных, подчиняющихся нормальному закону распределения, применялся коэффициент корреляции Пирсона $(p<0,05)$.

Для проверки значимости различий между выборками использовались двухвыборочный t-критерий Стьюдента для зависимых выборок, если распределение подчинялось нормальному закону, и ранговый t-критерий Уилкоксона для зависимых выборок, если закон распределения был отличен от нормального.

Исходя из периода отбора пробы грунтовых вод и почв, полевые работы были разделены на две группы: 1) начало сельскохозяйственного сезона (отбор в начале июня); 2) окончание сельскохозяйственного сезона (отбор в сентябре-октябре). Статистическая обработка и анализ полученных данных производились как с учетом сезона пробоотбора, так и с учетом глубины отбора для проб почв.

\section{РЕЗУЛЬТАТЫ И ОБСУЖДЕНИЕ}

\section{Химический состав подземных вод}

Подземные воды, отобранные для исследований миграции соединений азота, являются гидрокарбонатными кальциевыми и кальциево-магниевыми, преимущественно нейтральными, пресными по значению минерализации (таблица 1), что соответствует данным, полученным в работах [3, 5] при исследовании подземных вод юга Томской области и Томского района, в частности.

Концентрация $\mathrm{C}_{\text {орг }}$ изменяется от значений ниже предела обнаружения (<1 мг/л) до 5,90 мг/л. Значительных отличий в распределении по сезо- 
Химический состав подземных вод района исследований

[Table 1. Chemical composition of groundwater in the study area]

\begin{tabular}{|c|c|c|c|c|c|c|c|c|}
\hline \multirow[t]{2}{*}{$\begin{array}{l}\text { Показатель } \\
\text { / Parameter }\end{array}$} & \multirow{2}{*}{$\begin{array}{c}\text { Единица } \\
\text { измере- } \\
\text { ния / Unite }\end{array}$} & Min & Max & $\begin{array}{l}\text { Среднее } \\
\text { /Average }\end{array}$ & Min & Max & $\begin{array}{l}\text { Среднее } \\
\text { /Average }\end{array}$ & \multirow{2}{*}{$\begin{array}{c}\text { Фоновое } \\
\text { значение* } \\
\text { /Background* }\end{array}$} \\
\hline & & \multicolumn{3}{|c|}{ Лето / Summer } & \multicolumn{3}{|c|}{ Осень / Autumn } & \\
\hline $\mathrm{pH}$ & & 7,3 & 7,6 & 7,4 & 6,7 & 7,8 & 7,3 & 7,12 \\
\hline $\mathrm{Eh}$ & $\mathrm{MB} / \mathrm{mV}$ & -140 & 201 & 6 & -136 & 76 & -10 & - \\
\hline $\mathrm{O}_{2}$ & \multirow{16}{*}{$\begin{array}{l}\text { мг/л / } \\
\mathrm{mg} / \mathrm{L}\end{array}$} & 0,73 & 5,15 & 2,24 & 0,75 & 6,70 & 3,47 & - \\
\hline $\mathrm{NH}_{4}^{+}$ & & $<0,05$ & 0,57 & 0,27 & $<0,05$ & 0,76 & 0,27 & 0,41 \\
\hline $\mathrm{NO}_{2}^{-}$ & & $<0,02$ & 0,22 & 0,07 & $<0,02$ & 0,20 & 0,10 & 0,08 \\
\hline $\mathrm{NO}_{3}^{-}$ & & 0,26 & 6,2 & 2,8 & 0,10 & 14,0 & 4,6 & 1,09 \\
\hline $\mathrm{CO}_{2}$ & & $<3$ & 8,8 & 5,3 & $<10$ & 82,2 & 38,3 & 24,4 \\
\hline $\mathrm{CO}_{3}{ }^{2-}$ & & $<10$ & 19,2 & 11,5 & $<3$ & 28,0 & 5,3 & - \\
\hline $\mathrm{HCO}_{3}^{-}$ & & 94 & 434 & 289 & 110 & 453 & 337 & 312 \\
\hline $\mathrm{SO}_{4}{ }^{2-}$ & & $<3$ & 35,3 & 17,2 & $<2$ & 49,2 & 17,5 & 8,04 \\
\hline $\mathrm{Cl}^{-}$ & & 1,7 & 44,6 & 18,4 & 1,1 & 51,4 & 20,6 & 12,4 \\
\hline $\mathrm{Ca}^{2+}$ & & 23,3 & 122 & 80,0 & 32,0 & 117 & 90,3 & 49,8 \\
\hline $\mathrm{Mg}^{2+}$ & & 6,1 & 34,8 & 15,2 & 7,9 & 21,3 & 14,8 & 22,1 \\
\hline $\mathrm{Na}^{+}$ & & 4,2 & 37,4 & 13,7 & 6,8 & 31,0 & 17,5 & 32,3 \\
\hline $\mathrm{K}^{+}$ & & 0,9 & 9,6 & 3,9 & 0,7 & 16,6 & 5,4 & 3,38 \\
\hline TDS & & 154 & 691 & 446 & 191 & 631 & 512 & 457 \\
\hline $\mathrm{C}_{\mathrm{opr}} / \mathrm{DOC}$ & & $<1$ & 5,9 & 2,1 & 1,4 & 4,4 & 2,6 & 5,06 \\
\hline $\mathrm{N}_{\text {общ }} / \mathrm{TN}$ & & $<1$ & 2,7 & 1,7 & $<1$ & 3,1 & 1,2 & - \\
\hline ПОК /PI & \multirow{2}{*}{$\begin{array}{l}\mathrm{MrO}_{2} / \mathrm{J} / \\
\mathrm{mgO}_{2} / \mathrm{L}\end{array}$} & 2,2 & 8,0 & 4,9 & 0,76 & 6,8 & 2,5 & - \\
\hline ХПК /COD & & 1,7 & 23,5 & 9,2 & 2,6 & 22,1 & 10,4 & - \\
\hline
\end{tabular}

Примечания: «-» - нет данных;TDS - минерализация.

*3а фоновые значения приняты средние значения показателей для подземных вод зоны гипергенеза провинции умеренного влажного климата ландшафтов южной тайги по данным С. Л. Шварцева [9].

[Notes: “-" - no data; TDS - total dissolved solids; PI - permanganate index; COD - chemical oxygen demand; DON - dissolved organic carbon; TN - total nitrogen.

*Background level is given according to data of S. L. Shvartsev for groundwater of the upper part of geological cross section in south taiga zone under temperate humid climate [9]]

нам выявлено не было. Максимальные концентрации характерны для проб, отобранных в поселке Аникино. Также ведут себя и значения ХПК. Что касается значений ПОК, то наблюдается некоторое их повышение в летний период, по сравнению с осенним. Концентрация $\mathrm{CO}_{2}$ изменяется от значений ниже предела обнаружения (<3 мг/л) до 82,2 мг/л. При этом наблюдается очевидное повышение концентрации растворенной углекислоты в осенний период. Это может быть связано с процессом минерализации органического вещества, который, протекая в течение сельскохозяйственного сезона, ведет к аккумуляции $\mathrm{CO}_{2}$. Это подтверждается отрицательной корреляцией меж- ду значением ПОК и концентрацией $\mathrm{CO}_{2}\left(r^{2}=-0,73\right)$. Следует отметить, что статистически значимые отличия между выборками проб, отобранных в различные сезоны, отмечаются только для концентрации $\mathrm{CO}_{2}$ и значения ПОК. Отрицательная корреляция между концентрацией $\mathrm{NH}_{4}^{+}$и значением ПОК, а в осенний период и значением ХПК, также доказывает протекание процесса минерализации азотсодержащей органики в водоносном горизонте.

Значения Еh подземных вод варьируются в широких пределах, от -140 до 201 мВ. Восстановительная обстановка характерна для подземных вод, отобранных на территории поселков Мирный 
Поведение соединений азота и их трансформация в системе почва-подземные воды сельскохозяйственных ландшафтов Западной Сибири

Содержание соединений азота и гумуса в почвах района исследований

[Table 2. Content of nitrogen compounds and humus in soils of the study area]

\begin{tabular}{|c|c|c|c|c|}
\hline $\begin{array}{c}\text { Показатель / } \\
\text { Parameter }\end{array}$ & $\begin{array}{c}\text { Глубина отбора, м / } \\
\text { Sampling depth, m }\end{array}$ & $\begin{array}{c}\text { Минимальное } \\
\text { значение / } \\
\text { Minimum } \\
\end{array}$ & $\begin{array}{c}\text { Максимальное } \\
\text { значение / } \\
\text { Махіmum } \\
\end{array}$ & $\begin{array}{c}\text { Среднее } \\
\text { значение / } \\
\text { Average } \\
\end{array}$ \\
\hline \multirow{2}{*}{$\mathrm{pH}$} & $0,1-0,3$ & 4,31 & 7,27 & 6,25 \\
\hline & $0,9-1,1$ & 4,14 & 7,76 & 5,93 \\
\hline \multirow{2}{*}{$\begin{array}{c}\mathrm{NO}_{3}^{-}, \mathrm{M} \Gamma / \mathrm{\kappa} \Gamma / \\
\mathrm{mg} / \mathrm{kg}\end{array}$} & $0,1-0,3$ & 2,97 & 26,3 & 9,64 \\
\hline & $0,9-1,1$ & 1,40 & 9,20 & 3,67 \\
\hline \multirow{2}{*}{$\begin{array}{c}\mathrm{N}_{\text {общ, }}, \% \text { / } \\
\mathrm{TN}, \%\end{array}$} & $0,1-0,3$ & 0,10 & 0,60 & 0,27 \\
\hline & $0,9-1,1$ & 0,04 & 0,21 & 0,08 \\
\hline \multirow{2}{*}{$\begin{array}{c}\mathrm{NH}_{4}^{+}, \mathrm{мг} / \mathrm{кг} / \\
\mathrm{mg} / \mathrm{kg}\end{array}$} & $0,1-0,3$ & 4,58 & 25,8 & 12,1 \\
\hline & $0,9-1,1$ & 3,39 & 10,5 & 6,06 \\
\hline \multirow{2}{*}{$\begin{array}{l}\text { Гумус, \% / } \\
\text { Humus, \% }\end{array}$} & $0,1-0,3$ & 5,30 & 10,7 & 8,18 \\
\hline & $0,9-1,1$ & 1,75 & 8,16 & 5,15 \\
\hline
\end{tabular}

и Трубачево (ТО2, ТО3, ТО4), СТ Нерудник (ТО8), а также подземных вод точки ТО5 в поселке Аникино, отобранных в летний сезон и начале осеннего периода. В целом значения Еh достаточно низкие для подземных вод верхней гидродинамической зоны, что может быть результатом поступления в водоносный горизонт органических веществ с их последующим окислением растворенным кислородом. Кислород является основным окислителем в подземных водах. Это подтверждается тесной корреляционной взаимосвязью между показателем Еh и концентрацией $\mathrm{O}_{2}\left(r^{2}=0,81\right)$.

В районе поселка Мирный и поселка Трубачево механизм формирования восстановительных условий носит более сложный характер. При опробовании здесь наблюдался слабый запах сероводорода, а баланс форм азота смещен в сторону его восстановленных форм $\left(\mathrm{NH}_{4}^{+}, \mathrm{NO}_{2}^{-}\right)$, в отличии от остальных точек опробования, где даже при восстановительной обстановке преобладает $\mathrm{NO}_{3}^{-}$. Однако зависимость между концентрациями соединений азота и $\mathrm{O}_{2}$, а именно увеличение концентрации $\mathrm{NO}_{2}^{-}$и $\mathrm{NO}_{3}^{-}$и уменьшение концентрация $\mathrm{NH}_{4}^{+}$с ростом содержания растворенного кислорода, указывает на существенное влияние окислительно-восстановительных условий на баланс форм азота в водоносном горизонте.

Наиболее высокие концентрации $\mathrm{NO}_{3}{ }^{-}$наблюдаются в подземных вода поселка Аникино (до 14,0 мг/л) и СТ Нерудник (до 9,3 мг/л). Незначительные превышения концентрации $\mathrm{NO}_{2}^{-}$относительно фонового значения также наблюдаются в подземных водах поселка Аникино. Несмотря на низкие значения $\mathrm{Eh}$, концентрация $\mathrm{NH}_{4}^{+}$изменяется от значений ниже предела обнаружения $(<0,05$ мг/л) до 0,76 мг/л и в целом соответствует фоновой концентрации для подземных вод ландшафтов южной тайги. Следует отметить, что в точке, которая располагается на границе припоселкового кедровника, также отмечается повышенные концентрации $\mathrm{NO}_{3}^{-}$(до 6,2 мг/л) и $\mathrm{NO}_{2}^{-}$(до 0,15 мг/л). И это несмотря на то, что ведение хозяйственной деятельности в пределах припоселкового кедровника ограничено, а эта точка изначально была выбрана как фоновая. В грунтовых водах на границе кедровника наблюдаются признаки антропогенного загрязнения.

Концентрация общего азота изменяется от значений ниже предела обнаружения (<1 мг/л) до 3,1 мг/л, при среднем значении 1,3 мг/л. В летний сезон значения концентрации $\mathrm{N}_{\text {обш }}$ несколько выше, чем в осенний. Определенные расчетным путем концентрации $\mathrm{N}_{\text {орг }}$ показывают, что эту разницу обуславливает повышенная концентрация именно органических соединений азота в летний период.

\section{Химический состав почв}

Водородный показатель исследуемых почв изменяются в пределах от 4,14 до 7,76, а его среднее значение несколько уменьшается с глубиной (таблица 2). Таким образом, реакция среды в основном нейтральная, либо слабокислая. Нейтральная реакция среды характерна для почв, отобранных в поселке Аникино, в то время как слабокислая - 
для окрестностей поселка Мирный и садового товарищества Нерудник.

Содержание $\mathrm{N}_{\text {общ }}$ в исследуемых почвах в осенний период колеблется в пределах от 0,04\% до $0,30 \%$. Содержание в летний период изменяется от 0,04\% до 0,60\%. Содержание общего азота, как и его минеральных форм $\left(\mathrm{NO}_{3}^{-}, \mathrm{NH}_{4}^{+}\right)$, а также гумуса закономерно снижается с глубиной (таблица 2). Различия в распределении компонентов по глубине согласно значениям t-критерия Стьюдента являются статистически значимыми, за исключением изменения показателя $\mathrm{pH}$.

Содержание аммонийного азота в летний период варьирует в пределах от 5,18 мг/кг до 25,8 мг/кг, снижаясь к осени (3,39-16,2 мг/кг). Содержание $\mathrm{NO}_{3}{ }^{-}$в гумусово-элювиальном слое в осенний период составляет от 1,42 до 16,6 мг/кг. В летний период оно несколько выше (1,40-26,3 мг/кг). Содержание гумуса также выше в образцах, отобранных в летний период (2,47-10,68 \%) по сравнению с окончанием сельскохозяйственного сезона $(1,53$ 9,37\%). Подобное распределение компонентов по сезонам можно связать с процессом поступления органических веществ в начале сельскохозяйственного сезона, их минерализации и последующего потребления минеральных форм азота растениями в течение сельскохозяйственного сезона, а также с их выносом из почвенной толщи в результате просачивания атмосферных осадков и ирригации. Следует отметить, что выявленные зависимости между средними значениями показателей в различные сезоны не являются статистически значимыми.

Для почвенного покрова характерна статистически значимая корреляция между содержанием гумуса и $\mathrm{N}_{\text {общ }}\left(r^{2}=0,52\right)$. Такая связь указывает на значительную роль органического вещества в обогащении почвы соединениями азота. Также наблюдается статистически значимая зависимость между содержаниями $\mathrm{N}_{\text {общ }}$ и $\mathrm{NO}_{3}^{-}\left(r^{2}=0,43\right)$ и тесная положительная корреляция Noбщ с $\mathrm{NH}_{4}^{+}\left(r^{2}=0,85\right)$, поскольку эти минеральные формы азота являются преобладающими в почве. Обращает на себя внимание обратная зависимость между содержанием гумуса и $\mathrm{NO}_{3}{ }^{-}$в почве на глубине 1 м, то есть при уменьшении содержания органики концентрация $\mathrm{NO}_{3}^{-}$растет $\left(r^{2}=-0,58\right)$, что может косвенно указывать на более активное протекание нитрификации в почвенном горизонте на этой глубине. Преобладание нитрификации в почве ниже гумусового горизонта подтверждается данными авторов, полученными для агроландшафтов провинции Цзянси, КНР [18].
Поведение микроорганизмов в круговороте азота в почве и подземных водах

В пробах подземных вод и почв были изучены микроорганизмы, участвующие в круговороте азота.

Исследования азотфиксаторов в почве проводились путем изучения групп свободноживущих фиксаторов азота Azotobacter и Clostridium. Установлено, что Azotobacter в исследуемой почве встречается часто, особенно в летний период. Число почвенных комочков, обросших азотобактером, на среде Эшби составляло 5,85-100\%. Вариации связаны с чувствительностью этого азотфиксатора к кислотности почвы. Наибольшая численность приурочена к верхнему горизонту почвы. В исследуемой почве наиболее многочисленной группой несимбиотических азотфиксаторов являются анаэробные бактерии рода Clostridium, которые, в отличие от Azotobacter, обладают значительной толерантностью к повышенной почвенной кислотности. Установлено, что в летний период наблюдается тенденция к снижению численности этих микроорганизмов. Это возможно связано с применением удобрений, которые уменьшают плотность изучаемой почвы. Уменьшение плотности приводит к развитию аэробных процессов. Следует также отметить, что в осенний период большая численность бактерий рода Clostridium характерна для верхнего горизонта почвы, в то время как в летний период их численность с глубиной практически не изменяется, а в некоторых точках наоборот, увеличивается (при общем снижении численности по сравнению с осенним сезоном). Вероятно, это связано с увеличением влажности верхнего горизонта почвы в осенний период.

Наибольшая численность аммонифицирующих бактерий в почве также приходится на летний период. Поступление органического вещества с удобрениями в почвенный горизонт в начале сельскохозяйственного сезона, вероятно, стимулирует рост численности этих микроорганизмов. С увеличением глубины численность аммонификаторов в основном уменьшается. Положительная корреляция численности азотфиксаторов и аммонификаторов с содержанием гумуса подтверждает, что данные группы микроорганизмов более активны при обеспеченности почв органическим веществом.

Нитрифицирующие бактерии активно себя проявили в пробах, отобранных в осенний период. Зачастую для нитрифицирующих микроорганизмов наблюдается увеличение численности на глубине 1 м, что нехарактерно для рассмотренных 
Поведение соединений азота и их трансформация в системе почва-подземные воды сельскохозяйственных ландшафтов Западной Сибири

Изотопный состав нитратов, растворенных в подземных водах района исследований

[Table 3. Isotopic composition of nitrates dissolved in groundwater of the study area]

\begin{tabular}{|c|c|c|c|c|c|}
\hline $\begin{array}{l}\text { Номер точки } \\
\text { опробования / } \\
\text { Sample number }\end{array}$ & $\delta^{15} \mathrm{~N}, \% o$ & $\delta^{18} \mathrm{O}, \%$ & $\begin{array}{l}\text { Номер точки } \\
\text { опробования / } \\
\text { Sample number }\end{array}$ & $\delta^{15} \mathrm{~N}, \% \circ$ & $\delta^{18} \mathrm{O}, \%$ \\
\hline \multicolumn{3}{|c|}{ Лето (2017 г.) / Summer (2017) } & \multicolumn{3}{|c|}{ Осень (2018 г.) / Autumn (2018) } \\
\hline TO1 & 13,8 & $-1,85$ & TO1 & 11,5 & $-2,12$ \\
\hline TO5 & 6,07 & $-7,74$ & TO5 & 9,21 & $-6,53$ \\
\hline TO6 & 8,55 & $-4,74$ & TO6 & 13,4 & $-5,05$ \\
\hline TO7 & 17,9 & $-0,45$ & TO7 & 22,4 & 3,34 \\
\hline TO8 & 9,28 & $-4,45$ & TO8 & 11,0 & $-1,21$ \\
\hline
\end{tabular}

выше групп. Это подтверждает сделанный ранее вывод о том, что нитрификация активнее протекает именно на этой глубине.

Наибольшее количество денитрификаторов также было выявлено в осенний период. Возможно, из-за повышения влажности почвы. Максимумы численности денитрификаторов приходится на верхний почвенный горизонт. С увеличением глубины их количество снижается.

Азотофиксирующие бактерии в подземных водах наибольшую активность проявляют в летний период. Аммонифицирующие, нитрифицирующие и денитрифицирующие бактерии в наибольшем количестве представлены в пробах, отобранных в осенний период. Численность аммонифицирующих, нитрифицирующих и денитрифицирующих микроорганизмов в подземных водах положительно коррелирует с концентрацией $\mathrm{CO}_{2}$, что указывает на их существенную роль в минерализации органического вещества.

Изотопный состав нитратов, растворенных в подземных водах

С целью выявления источников соединений азота в подземных водах района исследований и процессов их трансформации был изучен изотопный состав соединения $\mathrm{NO}_{3}^{-}$, растворенного в подземных водах. Ввиду низких концентраций нитратов и мешающего влияния иона аммония в пробах, отобранных в районе поселка Мирный и поселка Трубачево, изотопный состав $\mathrm{NO}_{3}^{-}$был изучен на примере подземных вод поселка Аникино, СТ Нерудник и подземных вод колодца на границе кедровника (таблица 3 ).


$22,4 \%$, при среднем значении $12,3 \%$, т.е. нитратион в подземных водах обогащен тяжелыми изотопами азота, что можно связать с использованием отходов животноводства в качестве удобрения на исследуемой территории $[19,20]$. Значения $\delta^{18} \mathrm{O}-\mathrm{NO}_{3}{ }^{-}$изменяется от $-7,74$ до $3,34 \%$ при среднем значении $-3,08 \%$. Такие значения обычно наблюдаются при протекании процесса нитрификации, которое приводит к фракционированию изотопов кислорода в процессе формирования нитрат-иона [15].

Для детальной оценки источников поступления нитрат-иона в подземные воды использована диаграмма зависимости $\delta^{15} \mathrm{~N}_{-} \mathrm{NO}_{3}{ }^{-}$от $\delta^{18} \mathrm{O}_{-} \mathrm{NO}_{3}{ }^{-}$ с нанесением данных об изотопном составе возможных источников азота. Как показано на рисунке 2, практически все точки опробования лежат в пределах поля, соответствующего изотопному составу $\mathrm{NO}_{3}{ }^{-}$в органических удобрениях (отходах животноводства) и бытовых сточных водах. Учитывая отсутствие систем очистки сточных вод и централизованной системы водоотведения и канализации в районе исследований, поступление соединений азота со сточными водами весьма вероятно.

Используя данные об изотопном составе нитратов, можно проследить протекание денитрификации. По данным различных авторов $[10,11,13]$ этот процесс приводит к утяжелению изотопного состава $\mathrm{NO}_{3}{ }^{-}$в соотношении $\delta^{15} \mathrm{~N}: \delta^{18} \mathrm{O}$ от $2: 1$ до $1: 1$. Исходя из значений изотопных отношений, протекание денитрификации можно предположить в подземных водах поселка Аникино. Изотопный состав нитратов в точках ТО5, ТО6 и ТО7 изменяется в сторону утяжеления в направлении потока подземных вод, при этом рост значений $\delta{ }^{15} \mathrm{~N}: \delta^{18} \mathrm{O}$ приблизительно соответствует 2:1 (рис. 2). Но концентрация нитратов возрастает от ТО5 к ТО7. Таким образом, утяжеление изотопного состава нитратов в этом случае, скорее всего, связано с миграцией загрязнителей вниз по потоку подземных вод. Возможность протекания денитрификации полностью исключить нельзя, особенно в осенний 


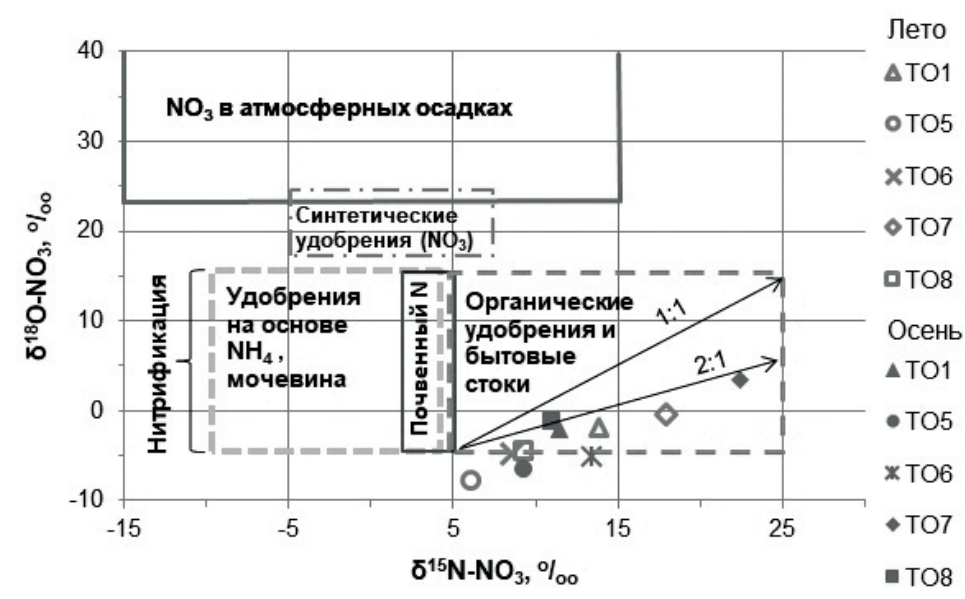

Puc. 2. Зависимость $\delta{ }^{15} \mathrm{~N}_{-} \mathrm{NO}_{3}^{-}$от $\delta^{18} \mathrm{O}-\mathrm{NO}_{3}^{-}$в исследуемых подземных водах (данные по изотопному составу $\mathrm{NO}_{3}^{-}$источников азота адоптированы из [19-22])

[Fig. 2. Diagram of $\delta^{15} \mathrm{~N}-\mathrm{NO}_{3}^{-}$vs. $\delta^{18} \mathrm{O}_{-} \mathrm{NO}_{3}^{-}$in groundwater under study (isotopic characteristics of nitrate sources are adopted from [19-22])]

период, принимая во внимание увеличение численности денитрификаторов, а также их взаимосвязь с содержанием растворенной углекислоты в подземных водах.

Облегчение изотопного состава $\mathrm{NO}_{3}^{-}$по кислороду в точках TO5 и ТО6 может происходить при быстром протекании цикла превращений азота в условиях низких его концентраций (около 15 мкмоль/л) [12].

Следует отметить, что в осенний период нитраты характеризуются более тяжелым изотопным состав, как по азоту, так и по кислороду, чем в летний период. Согласно расчетам разница является статистически значимой. Это указывает на накопление загрязнителей в водоносном горизонте в течение сельскохозяйственного сезона. Подобная картина наблюдалась и для нитратов, растворенных в грунтовых водах, приуроченных к ландшафтам рисовых почв в провинции Цзянси КНР [18].

\section{ЗАКЛЮЧЕНИЕ}

Данные о химическом и микробиологическом составе почв и подземных вод указывают на поступление органического вещества, в частности азотсодержащего, в начале сельскохозяйственного сезона, что обеспечивает активность азотфиксирующих и аммонифицирующих бактерий в почве, а также вызывает формирование восстановительных условий в водоносном горизонте. При этом баланс форм азота в подземных водах в большинстве случаев остается смещен в сторону нитрат-иона. Нитрификаторы и денитрификаторы более активны в осенний период. Выявленные зависимости в поведении соединений азота и микро- организмов в почве и подземных водах указывают на то, что нитрификация протекает в почвенном горизонте на глубине порядка 1 м. В то время как азотфиксация и аммонификация протекают, главным образом, в приповерхностном горизонте почвы. В водоносном горизонте в поселке Аникино изотопный состав растворенных нитратов несет признаки протекания денитрификации. Более вероятно утяжеление изотопного состава нитратов связано с накоплением загрязнителей вниз по потоку подземных вод. На накопление загрязнителей также указывает более тяжелый изотопный состав нитратов в осенний период по сравнению с началом сельскохозяйственного сезона. Следует отметить, что накопление соединений азота в подземных водах может быть связано с поступлением бытовых сточных вод в водоносный горизонт, поскольку в районе исследований отсутствуют системы очистки сточных вод и канализации.

\section{СПИСОК ЛИТЕРАТУРЫ}

1. Беус А.А., Григорян С. В. Геохимические методы поисков и разведки месторождений твердых полезнblx ископаемых. Москва, Недра, 1975. 280 с.

2. Дюкарев А.Г. Ландиафтно-динамические аспекты таежного почвообразования в Западной Сибири. Томск, изд-во НТЛ, 2005. 284 с.

3. Зиновик К. В., Хващевская А. А., Солдатова Е. А. Химический состав подземных вод нецентрализованных источников водоснабжения Томского района Томской области // Вопросы естествознания, 2018, № 1(15), c. $97-102$.

4. Крайнов С. Р., Закутин В. П. Загрязнение подземных вод в сельскохозяйственных регионах. Москва, Геоинформмарк, 1993. 86 с. 
5. Лепокурова О.Е., Иванова И. С., Шварцев С. Л., Колубаева Ю.В., Наливайко Н.Г. Химический и микробиологический состав подземных вод децентрализованного водоснабжения южных и центральных районов Томской области // Известия Томского политехнического университета. Инжиниринг георесурсов, 2016, т. 327, № 5, с. 29-41.

6. Непряхин Е. М. Почвы Томской области. Томск, изд-во Том. ун-та, 1977. 438 с.

7. Нетрусов А.И., Егорова М.А., Захарчук Л. М. Практикум по микробиологии. Москва, Издательский центр «Академия», 2005. 608 с.

8. Савичев О.Г. Водные ресурсы Томской области. Томск, Изд-во Томского политехнического университета, 2011. $224 \mathrm{c.}$

9. Шварцев С. Л. Гидрогеохимия зоны гипергенеза. 2-е изд., испр. и доп. Москва, Недра, 1998. 366 с.

10. Aravena R., Robertson W.D. Use of multiple isotope tracers to evaluate denitrification in ground water: study of nitrate from a large-flux septic system plume // Ground water, 1998, vol. 36, pp. 975-982.

11. Fukada T. A., Hiscock K. M., Dennis P.F., Grischek T. A dual isotope approach to identify denitrification in groundwater at a river-bank infiltration site // Water Research, 2003, vol. 37, no. 13, pp. 3070-3078.

12. Granger J., Sigman D. M., Lehmann M.F., Tortell P. D. Nitrogen and oxygen isotope fractionation during dissimilatory nitrate reduction by denitrifying bacteria // Limnology and Oceanography, 2008, vol. 53, no 6, pp. 2533-2545.

13. Kendall C. Tracing nitrogen sources and cycling in catchments // Isotope tracers in catchment hydrology / Eds. C. Kendall, J. J. McDonnell. Amsterdam, Elsevier, 1998, pp. 519-576.

14. Nikolenko O., Jurado A., Borges A. V., Knöller K., Brouyere S. Isotopic composition of nitrogen species in groundwater under agricultural areas: A review // Science of the Total Environment, 2018, vol. 621, pp. 1415-1432.

15. Sebilo M., Billen G., Mayer B., Billiou D., Grably M., Garnier J., Mariotti A. Assessing nitrification and denitrification in the Seine River and estuary using chemical and isotopic techniques // Ecosystems, 2006, vol. 9. pp. 564577.

16. Shvartsev S. L. Geochemistry of fresh groundwater in the main landscape zones of the Earth // Geochemistry International, 2008, vol. 46, no 13, pp. 1285-1398.

17. Sigman D. M., Casciotti K. L., Andreani M., Barford C., Galanter M., Böhlke J. K. A bacterial method for the nitrogen isotopic analysis of nitrate in seawater and freshwater // Analytical Chemistry, 2001, vol. 73, pp. 41454153.

18. Soldatova E., Dong Y., Li J., Liu Y., Zan J., Boeckx P., Sun Z. Nitrogen transformation and pathways in the shallow groundwater-soil system within agricultural landscapes // Environmental Geochemistry and Health, 2020. DOI: https://doi.org/10.1007/s10653-020-00733-w

19. Widory D., Petelet-Giraud E., Negrel P., Ladouche B. Tracking the sources of nitrate in groundwater using coupled nitrogen and boron isotopes: A synthesis // Environmental Science and Technology, 2005, vol. 39, no. 2, pp. 539-548.

20. Widory D., Petelet-Giraud E., Brenot A., Bronders J., Tirez K., Boeckx P. Improving the management of nitrate pollution in water by the use of isotope monitoring: the $\delta{ }^{15} \mathrm{~N}, \quad \delta{ }^{18} \mathrm{O}$ and $\delta{ }^{11} \mathrm{~B}$ triptych // Isotopes in Environmental and Health Studies, 2013, vol. 49, no 1, pp. 29-47.

21. Xue D., De Baets B., Botte J., Vermeulen J., Van Cleemput O., Boeckx P. Comparison of the silver nitrate and bacterial denitrification methods for determination of nitrogen and oxygen isotope ratios of nitrate in surface water // Rapid Communications in Mass Spectrometry, 2010, vol. 24, pp. 833-840.

22. Xue D., De Baets B., Vermeulen J., Botte J., Van Cleemput O., Boeckx P. Error assessment of nitrogen and oxygen isotope ratios of nitrate as determined via the bacterial denitrification method // Rapid Communications in Mass Spectrometry, 2010, vol. 24, no14, pp. 1979-1984.

Конфликт интересов: Авторы декларируют отсутствие явных и потенциальных конфликтов интересов, связанных с публикацией настоящей статьи.

Поступила в редакичию 22.06.2020 Принята к публикаџии 20.11.2020 


\title{
Behavior and Transformation of Nitrogen Compounds in the Soil-Ground Water System Within the Agricultural Landscapes of Western Siberia
}

\author{
E. A. Soldatova $a^{1 凶}$, D. V. Purgina ${ }^{2}$ \\ ${ }^{1}$ Vernadsky Institute of Geochemistry and Analytical Chemistry of Russian Academy of Sciences, \\ Russian Federation (19 Kosygin ast., Moscow, 119991) \\ ${ }^{2}$ National Research Tomsk Polytechnic University, Russian Federation \\ (30 Lenina ave., Tomsk, 634050)
}

\begin{abstract}
Purpose. The article considers the migration and transformation of nitrogen compounds in the soil-groundwater system within the agricultural landscapes of the Tomsk district (Tomsk region, Russia). Materials and methods. The studies were conducted based on the analysis of the chemical and microbiological composition of the ground-water and soil samples and the isotopic composition of nitrate ion dissolved in ground-water. The chemical composition of ground-water and soils was determined by titrimetry, potentiometry, flame photometry, photocolorimetry, fluorimetry, and high-temperature catalytic oxidation. Microbiological analysis of the groundwater and soil samples was carried out by bacterial cultivation on nutrient media for microorganisms related to the nitrogen cycle. The isotopic composition of nitrate ion was analyzed by bacterial denitrification using an isotope ratio mass spectrometer with a trace gas module. The geochemical data obtained were processed using mathematical statistics. Results. The research allowed identifying the processes affected nitrogen compound transformation during an agricultural season and determining their localization in the soil-groundwater system, including the influence of microflora on the transformation of nitrogen compounds. The studies also revealed the relationships between aquifer's geochemical conditions and processes occurring in soil.
\end{abstract}

Key words: biogeochemical cycle of nitrogen, aqueous migration, nitrates, ammonium, isotopic composition of nitrates, microbiological processes, Tomsk region.

Acknowledgements: the Authors thank K. V. Zinovik, V. V. Kramarenko, and T. S. Spiridonov for their assistance in organizing and conducting geochemical testing and sample preparation of soil samples.

Funding: research was supported by Russian Science Foundation, project 17-77-10017.

For citation: Soldatova E. A., Purgina D. V. Behavior and transformation of nitrogen compounds in the soil-groundwater system within the agricultural landscapes of Western Siberia. Vestnik Voronezskogo gosudarstvennogo universiteta. Seria Geografia. Geoekologia, 2020, No. 4, pp. 32-43. (In Russ.) DOI: https://doi.org/10.17308/geo.2020.4/3063

\section{REFERENCES}

1. Beus A. A., Grigoryan S. V. Geohimicheskiye metody poiskov i razvedki mestorozhdeniy tverdyh poleznyh iskopaemyh [Geochemical methods of exploration and prospecting of solid mineral deposits]. Moscow, Publ. Nedra, 1975. 280 p. (In Russ.)

2. Djukarev A. G. Landshaftno-dinamicheskiye aspekty tayezhnogo pochvoobrazovaniya $v$ Zapadnoy Sibiri [Landscape and dynamic aspects of taiga soil formation in Western Siberia]. Tomsk, Publ. NTL, 2005. 284 p. (In Russ.)

3. Zinovik K. V., Khvashevskaya A. A., Soldatova E. A. Chemical composition of groundwater of non-centralized water supply in the Tomsky district of Tomsk region. Voprosy estestvoznaniya, 2018, no. 1(15), pp. 97-102. (In Russ.)

4. Krainov S. R., Zakutin V.P. Zagryazneniye podzemnyh vod $v$ sel'skohozyaistvennyh regionah [Pollution of groundwater in agricultural regions]. Moscow, Publ. Geoinformmark, 1993. 86 p. (In Russ.)

5. Lepokurova O.E., Ivanova I.S., Shvartsev S.L., KolubaevaYu. V., Nalivayko N. G. Chemical and microbiological composition of groundwaters of decentralized water supply of southern and central districts of Tomsk region. Bulletin of the Tomsk Polytechnic University. Geo Assets Engineering, 2016, vol. 327, no 5, pp. 29-41. (In Russ.)

(C) Soldatova E. A., Purgina D. V., 2020

Evgeniya A. Soldatova, e-mail: sea@geokhi.ru

The content is available under Creative Commons Attribution 4.0 License. 
6. Nepryahin E. M. Pochvy Tomskoy oblasti [Soils of Tomsk region]. Tomsk, Publ. Tomskogo Universiteta, 1977. 438 p. (In Russ.)

7. Netrusov A. I., Egorova M. A., Zaharchuk L. M. Praktikum po mikrobiologii [Laboratory course on microbiology]. Moscow, Publ. centr "Akademiya", 2005. 608 p. (In Russ.)

8. Savichev O.G. Vodnyye resursy Tomskoy oblasti [Water resources of Tomsk region]. Tomsk, Publ. Tomskogo Politehnicheskogo Universiteta, 2011. 224 p. (In Russ.)

9. Shvartsev S.L. Gidrogeohimiya zony gipergeneza [Hydrogeochemistry of hypergenesis zone]. Moscow, Publ. Nedra, 1998. 366 p. (In Russ.)

10. Aravena R., Robertson W.D. Use of multiple isotope tracers to evaluate denitrification in ground water: study of nitrate from a large-flux septic system plume. Ground water, 1998, vol. 36, pp. 975-982.

11. Fukada T.A., Hiscock K.M., Dennis P.F., Grischek T. A dual isotope approach to identify denitrification in groundwater at a river-bank infiltration site. Water Research, 2003, vol. 37, no. 13, pp. 3070-3078.

12. Granger J., Sigman D.M., Lehmann M.F., Tortell P.D. Nitrogen and oxygen isotope fractionation during dissimilatory nitrate reduction by denitrifying bacteria. Limnology and Oceanography, 2008, vol. 53, no 6, pp. 25332545.

13. Kendall C. Tracing nitrogen sources and cycling in catchments. Isotope tracers in catchment hydrology. Eds. C. Kendall, J.J. McDonnell. Amsterdam, Elsevier, 1998, pp. $519-576$.

14. Nikolenko O., Jurado A., Borges A.V., Knöller K., Brouyere S. Isotopic composition of nitrogen species in groundwater under agricultural areas: A review. Science of the Total Environment, 2018, vol. 621, pp. 1415-1432.

15. Sebilo M., Billen G., Mayer B., Billiou D., Grably M., Garnier J., Mariotti A. Assessing nitrification and denitrification in the Seine River and estuary using chemi-

Солдатова Евгения Александровна

кандидат геолого-минералогических наук, старший научный сотрудник лаборатории моделирования гидрогеохимических и гидротермальных процессов Института геохимии и аналитической химии им. В.И. Вернадского Российской академии наук, г. Москва, Россия, ORCID: https://orcid.org/0000-0003-3967-4822, e-mail: sea@geokhi.ru

Пургина Дарья Валерьевна

кандидат геолого-минералогических наук, научный сотрудник Отделения геологии Инженерной школы природных ресурсов, Национальный исследовательский Томский политехнический университет, г. Томск, Россия, e-mail: purgina_darya@mail.ru cal and isotopic techniques. Ecosystems, 2006, vol. 9, pp. 564-577.

16. Shvartsev S.L. Geochemistry of fresh groundwater in the main landscape zones of the Earth. Geochemistry International, 2008, vol. 46, no. 13, pp. 1285-1398.

17. Sigman D.M., Casciotti K.L., Andreani M., Barford C., Galanter M., Böhlke J.K. A bacterial method for the nitrogen isotopic analysis of nitrate in seawater and freshwater. Analytical Chemistry, 2001, vol. 73, pp. 4145-4153.

18. Soldatova E., Dong Y., Li J., Liu Y., Zan J., Boeckx P., Sun Z. Nitrogen transformation and pathways in the shallow groundwater-soil system within agricultural landscapes. Environmental Geochemistry and Health, 2020. DOI: https://doi.org/10.1007/s10653-020-00733-w

19. Widory D., Petelet-Giraud E., Negrel P., Ladouche B. Tracking the sources of nitrate in groundwater using coupled nitrogen and boron isotopes: A synthesis. Environmental Science and Technology, 2005, vol. 39, no. 2, pp. 539-548.

20. Widory D., Petelet-Giraud E., Brenot A., Bronders J., Tirez K., Boeckx P. Improving the management of nitrate pollution in water by the use of isotope monitoring: the $\delta{ }^{15} \mathrm{~N}, \delta{ }^{18} \mathrm{O}$ and $\delta{ }^{11} \mathrm{~B}$ triptych. Isotopes in Environmental and Health Studies, 2013, vol. 49, no 1, pp. 29-47.

21. Xue D., De Baets B., Botte J., Vermeulen J., Van Cleemput O., Boeckx P. Comparison of the silver nitrate and bacterial denitrification methods for determination of nitrogen and oxygen isotope ratios of nitrate in surface water. Rapid Communications in Mass Spectrometry, 2010, vol. 24, pp. 833-840.

22. Xue D., De Baets B., Vermeulen J., Botte J., Van Cleemput O., Boeckx P. Error assessment of nitrogen and oxygen isotope ratios of nitrate as determined via the bacterial denitrification method. Rapid Communications in Mass Spectrometry, 2010, vol. 24, no14, pp. 1979-1984.

Conflict of interests: The authors declare no information of obvious and potential conflicts of interest related to the publication of this article.

Received: 22.06 .2020 Accepted: 20.11 .2020

Evgeniya A. Soldatova

Cand. Sci. (Hydrogeol.), Senior Researcher of the Laboratory of Modeling Hydrogeochemical and Hydrothermal Processes, Vernadsky Institute of Geochemistry and Analytical Chemistry of Russian Academy of Sciences, Moscow, Russian Federation, ORCID: https://orcid.org/0000-0003-3967-4822, e-mail: sea@geokhi.ru

Dariya V. Purgina

Cand. Sci. (Hydrogeol.), Researcher of Division for Geology, School of Earth Sciences and Engineering, National Research Tomsk Polytechnic University, Tomsk, Russian Federation, e-mail: purgina darya@mail.ru 